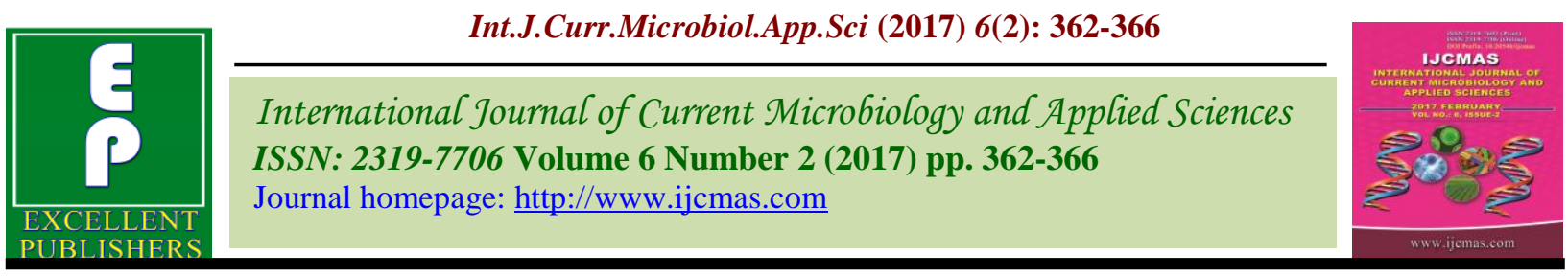

Original Research Article

http://dx.doi.org/10.20546/ijcmas.2017.602.040

\title{
Effectiveness of Insecticidal Sprays against Whitefly Checking Yellow Vein Mosaic Virus (YVMV) Incidence in Okra (Abelomoschus esculentus L. Moench)
}

\author{
K.S. Pagire*, V.U. Sonalkar, Dipali P. Thakare, V.V. Kalpande and V.M. Chavan \\ Indian Agriculture Research Institute, Regional Station, College of Agriculture, \\ Pune (M.S), India \\ *Corresponding author
}

\author{
A B S T R A C T
}

\begin{tabular}{|l}
\hline Ke y w o r d s \\
YVMV, Okra, \\
$\begin{array}{l}\text { Abelomoschus } \\
\text { esculentus. }\end{array}$ \\
\hline Article Info \\
\hline $\begin{array}{l}\text { Accepted: } \\
\text { 12 January } 2017 \\
\text { Available Online: } \\
\text { 10 February } 2017\end{array}$
\end{tabular}

Keywords

YVMV, Okra, Abelomoschus esculentus.

\section{Introduction}

Among vegetables, Okra (Abelomoschus esculentus L. Moench) commonly known as lady's finger in western style and 'bhendi' in Indian language, is of African origin. The crop is grown extensively in all Tropical and Subtropical parts of the world. It is cultivated throughout the India. Okra is said to be very useful against genitourinary disorders, spematorrhoea and chronic dysentery (Nadkarni, 1927). On an average 532660 ha area with the total production of 6346368 tonnes and yield level of $11.9 \mathrm{t} / \mathrm{ha}$ is under okra cultivation in India (Anonymous, 2014). Sastry et al., (1974) who reported that when plant were infected with yellow vein mosaic virus at 35 and 50 days after germination, the loss in yield was 83 and 49 percent respectively. Butani and Verma (1976) recorded 20 pests infesting the Okra crop is a high value vegetable which face considerable losses due to consistent damage caused by whitefly. Besides causing direct damage, whitefly acts as vector of yellow vein mosaic virus (YVMV), which is a major constraint for okra cultivation (Neeraja et al., 2004). The attempts have been made earlier to reduce the YVMV disease in okra by controlling the vector, whiteflies, with the use of insecticide (Debnath and Nath, 2002). Considering the importance of damage of yellow vein mosaic virus (YVMV) caused by whitefly to Okra crop, the present investigation have been undertaken to study the effectiveness of newer insecticides against vector of yellow 
vein mosaic virus (YVMV) infesting okra under field conditions.

\section{Materials and Methods}

The research work was carried out at experimental farm of I.A.R.I. Regional Station, Pune during kharif season. The experiment was laid out in randomized block design with three replications and eight treatments including untreated control. The certified seeds of okra variety "Pusa Sawani" were dibbled in medium block soil at spacing $30 \mathrm{~cm} \times 20 \mathrm{~cm}$. The insecticides were used in experiment viz., thimethoxam (25 WG) $0.005 \%$, imidacloprid (17.80SL) $0.01 \%$, spinosad (2.5 SC) $0.0025 \%$, oxydemetonmethyl (25 EC) $0.03 \%$, fenpropathrin (30EC) $0.02 \%$, triazophos (20 EC) $0.05 \%$ and acetamiprid (20SP) $0.005 \%$.The total two sprays at 15 days interval were given. Spraying of insecticide was initiated at 20 days after sowing.

Observations were recorded as the pre count and post count of whiteflies on top, middle and bottom leaf of randomly selected plants in each plot. The spraying of insecticide done on the next day of pre-count. The post count of adults whiteflies were taken on the selected leaves of labeled plants for each treatment on $3^{\text {rd }}, 7^{\text {th }}$ and $14^{\text {th }}$ day after spraying and the mortality adults of whitefly was worked out for each treatment.

The observations on yellow vein mosaic virus (YVMV) were taken on total number of plants and the plants showing yellow vein mosaic virus (YVMV) symptoms in each plot on $3^{\text {rd }}, 7$ th and $14^{\text {th }}$ days after each application of pesticides. Percentage of disease incidence was worked out for knowing the effect of insecticides on spread of disease. The per cent whitefly data was correlated with per cent YVMV incidence to work out correlation coefficients.

\section{Results and Discussion}

The data in table 1 after first spray it was observed that all the insecticidal treatments significantly recorded lower incidence of YVMV as compared to untreated control showing maximum 46.44 per cent incidence. Plots treated with thiomethoxam $(0.005 \%)$ got minimum of $3.37 \%$ incidence followed by treatments such as acetamiprid $(0.005 \%)$, imidacloprid $(0.01 \%)$, fenpropathrin $(0.02)$, triazophos $(0.05 \%)$ and oxydemeton-methyl $(0.03 \%)$ showing $3.89,3.89,5.55,6.11$ and 6.12 per cent incidence of YVMV on okra respectively. At Second spray the data on percent incidence of yellow vein mosaic virus (YVMV) on okra was revealed that all the treatments differed significantly over the untreated control. The treatment with thiomethixam $(0.005 \%)$ was most effective and recorded minimum incidence of YVMV i.e.10.56 per cent and was at par with acetamiprid $(0.005 \%)$, imidacloprid $(0.01 \%)$ and triazophos 14.72 per cent incidence of YVMV, respectively.

The average effect of both two sprays on the incidence of yellow vein mosaic virus on okra crop as studied after first and second spray which were pooled on the basis of 3,7 and 14 DAS of each application indicated that all the insecticides treated plots were significantly superior in checking the YVMV incidence on okra crop as compared to untreated control plots. The lowest incidence of YVMV i.e.6.94 per cent was recorded in the plots treated with thiomethoxam $(0.005 \%)$ followed by plots treated with acetamiprid $(0.005 \%)$ and imidacloprid $(0.01 \%)$ showing 7.92 and 8.06 per cent YVMV incidence, respectively. The plot treated with the thiomethoxam $(0.005 \%)$ was most effective treatment against incidence of yellow vein mosaic virus (YVMV) are in conformity with the findings of Yadav et al., (2007), who observed that the incidence of YVMV reduced to 22.14 per 
cent from 59.19 per cent in untreated control by using thiomethoxam $25 \mathrm{WG}$ at $100 \mathrm{~g} / \mathrm{ha}$, imidacloprid $17.8 \mathrm{SL}$ at $125 \mathrm{ml} / \mathrm{ha}$, monocrotophos $36 \mathrm{SL}$ at $800 \mathrm{ml} / \mathrm{ha}$, acetampird $20 \mathrm{SP}$ at $100 \mathrm{ml} / \mathrm{ha}$, carbosulfan $25 \mathrm{EC}$ at $600 \mathrm{ml} / \mathrm{ha}$ and neem oil at 2.5 litre/ha on mesta crop. The next best treatment of acetamiprid for minimizing the incidence of YVMV disease as reported in present investigations have been supported by findings of Gowdar et al., (2007), who observed two sprays of acetamiprid $20 \mathrm{SP}$ at
40 a.i./ha was effective in reducing the incidence of YVMV. Similarly, Yadav et al., (2007) indicated that acetamiprid $20 \mathrm{SP}$ at $100 \mathrm{ml} /$ ha was effective in reducing the incidence of whitefly as well as YVMD. The effectiveness of imidacloprid for minimizing incidence of YVMV as reported in present investigations are also in conformity with the results of Shivpuri et al., (2004), who proved imidacloprid applied as a seed dresser on okra gave better results with regards to reduction in YVMV.

Table.1 Effectiveness of insecticides for management of whitefly to reduce incidence of yellow vein mosaic virus (YVMV) in Okra

\begin{tabular}{lccc} 
Treatments & $\begin{array}{c}\text { \% of yellow vein } \\
\text { mosaic virus } \\
\text { (YVMV) after first } \\
\text { spray }\end{array}$ & $\begin{array}{c}\text { \% of yellow } \\
\text { vein mosaic } \\
\text { virus (YVMV) } \\
\text { after second } \\
\text { spray }\end{array}$ & $\begin{array}{c}\text { Average \% } \\
\text { incidence of yellow } \\
\text { vein mosaic virus } \\
\text { (YVMV) }\end{array}$ \\
\hline Thiomethoxam 005\% & $3.37(10.51) *$ & $10.56(18.95)$ & $6.94(15.27)$ \\
Imidacloprid 0.01 \% & $3.89(11.20)$ & $12.22(20.44)$ & $8.06(16.49)$ \\
Spinosad 0.0025\% & $10.00(18.31)$ & $27.22(31.37)$ & $18.61(25.48)$ \\
Oxydemeton-methyl 0.03\% & $6.12(14.28)$ & $19.44(26.10)$ & $12.78(20.92)$ \\
Fenpropathrin 0.02\% & $5.55(13.46)$ & $18.33(25.31)$ & $11.95(20.17)$ \\
Triazophos 0.05\% & $6.11(14.22)$ & $14.72(22.41)$ & $10.42(18.71)$ \\
Acetamiprid 0.005\% & $3.89(11.32)$ & $11.95(20.17)$ & $7.92(16.30)$ \\
Untreated (control) & $46.44(42.96)$ & $75.56(60.38)$ & $61.00(51.36)$ \\
S.E.m. \pm & 1.23 & 1.38 & 1.04 \\
C.D. at 5\% & 3.72 & 4.19 & 3.14 \\
\hline
\end{tabular}

Note: *Figures in parentheses are arc sin transformed value, DAS: Days after spraying

Table.2 Correlation Coefficients between mortality of whitefly and YVMV in Okra

\begin{tabular}{lccc}
\hline \multicolumn{1}{c}{ Particulars } & $\begin{array}{c}\text { Mortality of White } \\
\text { fly after first spray }\end{array}$ & $\begin{array}{c}\text { Mortality of White } \\
\text { fly after second } \\
\text { spray }\end{array}$ & $\begin{array}{c}\text { Average Mortality } \\
\text { of White fly of both } \\
\text { spray }\end{array}$ \\
\hline $\begin{array}{l}\text { Incidence of Yellow } \\
\begin{array}{l}\text { Vein Mosaic Virus } \\
\text { (YVMV) }\end{array}\end{array} \quad-0.948$ & -0.963 & -0.963 \\
\hline \multicolumn{2}{l}{ Correlation Coefficients at $1 \%, r=0.798$}
\end{tabular}

Correlation Coefficients at $1 \%, r=0.798$ 
Fig.1 Per cent incidence of yellow vein mosaic virus (YVMV) on okra

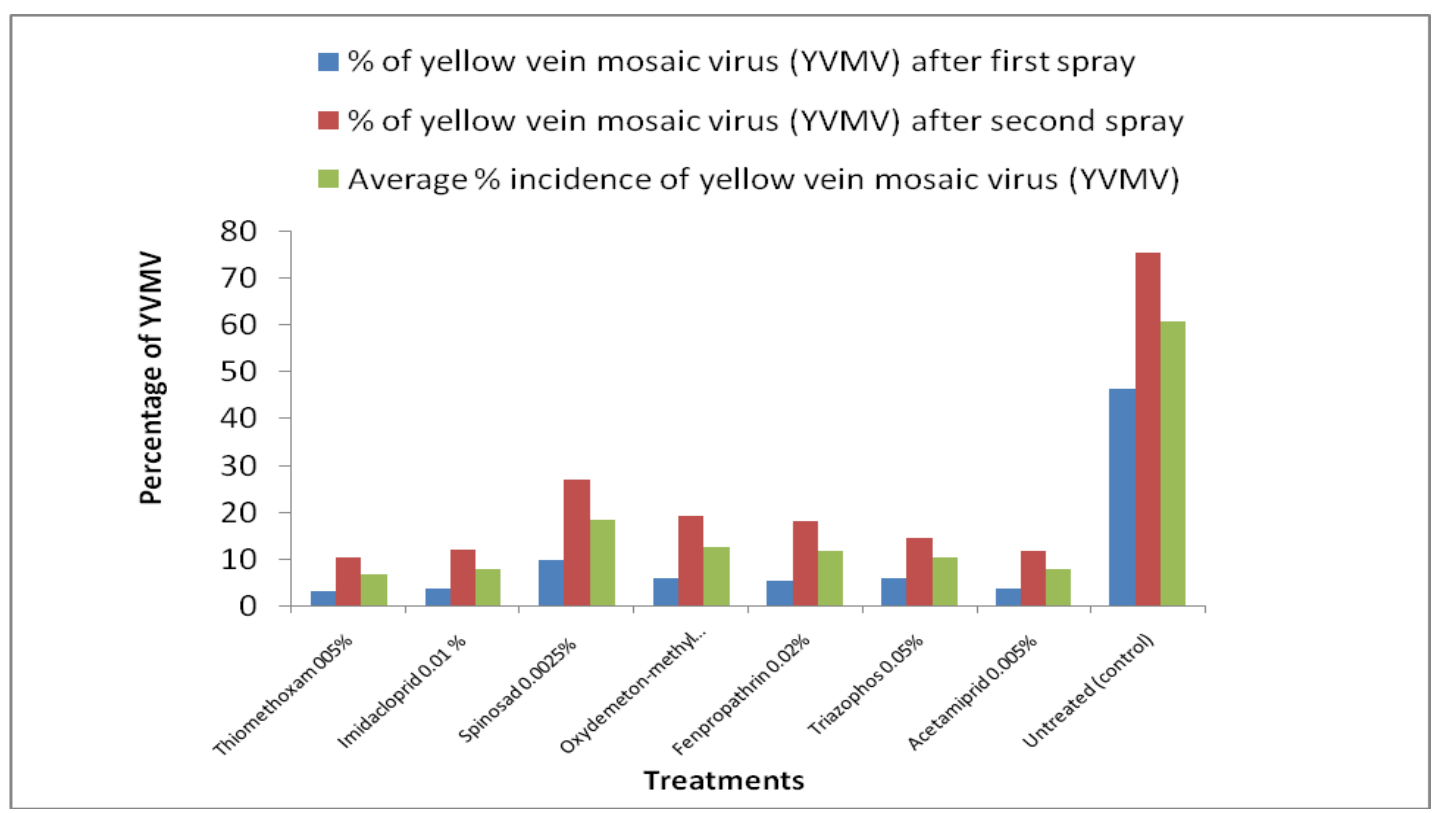

The effectiveness of imidacloprid as seed dresser was also authenticated by Mote et al., (1994), who found imidacloprid $15 \mathrm{gm} / \mathrm{kg}$ seed treatment resulted in least percentage of yellow vein mosaic affected plants of okra. Safdar-Ali et al., (2005) reported that imidacloprid as foliar application significantly reduced the OYVMV incidence on okra crop which was also corroborated by Yadav et al., (2007), who reported that imidacloprid 17.8 $\mathrm{SL}$ at $125 \mathrm{ml} / \mathrm{ha}$ reduced the incidence of YVMD and Gowdar et al., (2007) who found that acetamiprid, imidacloprid, triaziphos and monocrotophos resulted significant reduction in YVMV incidence shown in fig 1.

The data in table 2 revealed that the mortality of whitefly after first spray, second spray and average of both spray was negatively correlated with incidence on yellow vein mosaic virus (YVMV) incidence that means increase in mortality of white fly decrease the incidence of yellow vein mosaic virus (YVMV) and vice versa on okra. The present findings are in conformity with findings of the authors Board et al., (1993). The authors conducted field experiment to find out the relationship of $B$. tabaci population density and the incidence of yellow vein mosaic disease of okra in 1988 and 1989 cropping seasons. In both the years, the population of the vector reached a maximum size during the first week of October. Symptoms of YVMV appeared one week after infestation with $B$. tabaci. The disease percentage increased progressively with the corresponding increase in vector population. Correlation coefficients for the all three planting dates indicated highly significant relationship between adult whitefly population density and the incidence of YVMV.

Sindhumole et al., (2013) reported that correlation coefficients of YVM incidence with vector population computed during different crop stages revealed that morning and evening population of whitefly had significant association with disease occurrence from 50 DAS to final harvest. Besides, whitefly population during both the time at 50 DAS also had influence on YVM incidence during final harvest.

Thus, the findings of the current investigation 
concluded that, the treatment thiomethoxam 0.005 per cent was the most effective treatment for lower down the incidence of yellow vein mosaic virus (YVMV) on okra and followed by acetamiprid $(0.005 \%)$ and imidacloprid (0.01\%). Also, correlation between white fly and incidence of yellow vein mosaic virus was significant that means increase the mortality of white fly decreased the incidence of yellow vein mosaic virus (YVMV) on okra.

\section{References}

Anonymous. 2014. Indian Horticulture Database. National Horticulture Board, Ministry of Agriculture, Govt. of India.

Board, V.K., Puri, S.N., Brown, J.K. and Butler, G.D. 1993. Relationship of Bemisia tabaci population density and yellow vein mosaic disease incidence in okra. Pest Management and Economic Zool., 1(1): 14-19.

Butani, D.K. and Verma, S. 1976. Insect pests of vegetables and their control -3.Lady's finger. Pesticides, 10(7): 31-37.

Debnath, S. and Nath, P.S. 2002. Management of yellow vein mosaic disease of okra through insecticides, plant products and suitable varieties. Ann. Pl. Protec. Sci., 10: 340-342.

Gowdar, S.B., Ramesh Babu, H.H. and Reddy, N.A. 2007. Efficacy of insecticides on okra yellow vein mosaic virus and whitefly vector, Bemisia tabaci Genn. Ann. Pl. Protec. Sci., 15(1): 116-119.

Mote, U.N., Datkhile, R.V. and Pawar, S.A. 1994. Imidacloprid as a seed dresser against sucking pests of okra. Pestol., 18(3): 5-9.

Nadkarni, K.M. 1927. Indian Meteria Medica, Nadkarni and Co., Mumbai.

Neeraja, G., Vijayam., Chiranjeevi, C. and Gautam, B. 2004. Screening of okra hybrids against pests and diseases. Indian J. Pl. Protec., 32(11): 129-131.

Safadar-Ali., Khan, M.A., Habib, A., Rasheed, S. and Iftikar, Y. 2005. Management of yellow vein mosaic disease of okra through pesticide /bio-pesticide and suitable cultivars. Int. J. Agri. Biol., 7(1): 145-147.

Sastry, K.S.M. and Singh, S.J. 1974. Effect of yellow vein mosaic virus infection on growth and yield of okra crop. Ind. Phyl., 27: 316-317.

Shivpuri, D.R. and Lal, O.P. 2002. Bioefficacy of thiomethoxam in comparison to recommended insecticides against leaf hopper and whitefly of brinjal. J. Ent. Res., 26(3): 257-262.

Sindhumole, P. and Manju, P. 2013. Association of okra (Abelomoschus esculentus (L.) Moench) yellow vein mosaic virus incidence with population of its vectors under kerala conditions. Entomon., 38(3):131-138.

Yadav, U.S., Yadav, A. and Prasad, S.S. 2007. Efficacy and economics of certain new insecticides on vector whitefly, Bemisia tabaci (Genn.) causing yellow vein mosaic disease in mesta. Souvenif $7^{\text {th }}$ National Symp on plant protection options - Implementation and Feasibility, Abst.No.83, pp 75.

\section{How to cite this article:}

Pagire, K.S., V.U. Sonalkar, Dipali P. Thakare, V.V. Kalpande and Chavan, V.M. 2017. Effectiveness of Insecticidal Sprays against Whitefly Checking Yellow Vein Mosaic Virus (YVMV) Incidence in Okra (Abelomoschus esculentus L. Moench). Int.J.Curr.Microbiol.App.Sci. 6(2): 362-366. doi: http://dx.doi.org/10.20546/ijcmas.2017.602.040 